Original Article

\title{
SMOKING GENOTOXICITY IN PERIPHERAL BLOOD LYMPHOCYTES USING THE COMET ASSAY
}

\author{
Shobha S Shetty ${ }^{1} \&$ Hrishikesh Nachane ${ }^{2}$ \\ ${ }^{1}$ Associate Professor, Department of General Medicine, ${ }^{2}$ Intern \\ K.S. Hegde Medical Academy, Deralakatte, Nitte University, Mangalore 575018, Karnataka, India \\ Correspondence \\ Shobha S. Shetty \\ Associate Professor, Department of General Medicine, K.S. Hegde Medical Academy, Derlakatte, \\ Mangalore - 575 018, Karnataka, India \\ Mobile : +91 98800 08470, Phone - off : +91 824 2204471-76 E-mail : shobhashetty22@gmail.com
}

\section{Abstract :}

Background: Smoking has been shown to have a positive effect on DNA damage in almost all the cells of the body. Quantitative analysis of this damage will help in assessing the etiopathogenesis of various nicotine induced damage to the body. Comet assay has been an emerging tool in this regard and hence was applied by us to estimate the severity of DNA damage in smokers.

Aims \& Objectives: To evaluate the DNA genotoxicity in peripheral blood lymphocytes in smokers and their comparison with non smokers \& assess the quantitative damage.

Materials and methods: 30 smokers \& 20 non smokers were recruited \& their peripheral blood was taken for the comet assay to look for Olive moment \& Tail moment to quantitatively assess the DNA damage due to cigarette smoking.

Results: In our study there was no significant difference in the analysis of DNA damage (with regard to tail moment \& olive moment) in smokers versus non smokers (P value: more than 0.05 ).

Conclusions: Though smoking is known to cause DNA damage, we did not find significant differences between the two groups probably due to other multifactorial etiologies for genotoxicity.

Keywords: Comet Assay, DNA Damage, Genotoxicity, Smoking

\section{Introduction :}

The World Health Organization (WHO) ranks tobacco smoking among the 10 greatest risks to health. Cigarette smoke contains more than 4000 chemical agents several types of toxic components including carbon monoxide, nicotine, aromatic hydrocarbons and specially free radicals and reactive oxygen $\left(\mathrm{O}^{2-}\right)$. Many of them are known to be mutagens and carcinogens. ${ }^{[1]}$ Cigarette smoke induces cancer, emphysema, arteriosclerosis and other diseases after a delay of years ${ }^{[2]}$. The exact mechanism by which smoking contributes to

\begin{tabular}{|c|}
\hline Access this article online \\
\hline Quick Response Code \\
\hline
\end{tabular}
the pathogenesis of various diseases has not yet been identified in detail. One of the methods suggested is oxidative stress.

Reactive oxygen (ROS) and nitrogen species (RNS) are continuously generated in the biological system and play an important role in a wide variety of physiological and pathological processes, including cancer and emphysema. ${ }^{[3]}$ Cigarette smoke induces various forms of DNA damage, including singlestrand breaks (SSBs) ${ }^{[4,5]}$ and possibly double-strand breaks (DSBs) ${ }^{[6,7]}$. SSBs represent the initial DNA damage and are often used as a biomarker of exposure ${ }^{[8-10]}$. DSBs are considered to be more biologically relevant since they can lead to chromosome translocation and cancer if repaired improperly in addition to genetic instability and cell death if left unrepaired ${ }^{[11]}$.

The comet assay (single-cell gel electrophoresis, SCG or SCGE) is a well-established genotoxicity test for in vitro and in vivo testing of chemicals. ${ }^{[12,13]}$ Because of its ease of application, the comet assay is also being increasingly used in human biomonitoring. ${ }^{[14-16]}$ The parameter often used to evaluate DNA damage is the "tail moment", which is 
defined as the product of the tail length and the fraction of the total DNA content that is present in the tail. ${ }^{[17]}$ Other parameters used are "olive moment" and \% DNA in the tail. Olive moment is calculated as: (tail mean - head mean) $\mathrm{x}$ tail \% DNA/100. \% DNA in tail is 100-\%DNA in head.

This study was taken up to evaluate the effects of smoking on DNA assessed in the peripheral blood lymphocytes and to quantitatively assess the degree of DNA damage in the body cells.

\section{Materials \& Methods:}

\section{Subjects:}

A total of 50 subjects between the age group of 20-50 yrs were recruited for the studies. 30 subjects were smokers were selected from various departments of the hospital. 20 age and sex matched subjects were selected from the staff and employees of the hospital. Consent for experimentation was obtained from all the volunteers.

\section{Inclusion criteria:}

- Subjects of both sexes

- Age between 20-50 yrs

- Group 1: smokers

- Group 2: non-smokers (controls)

\section{Exclusion criteria:}

Diseases which cause DNA damage other than smoking:

- Blood disorders such as anaemias and blood dyscrasias

- Nutritional deficiencies

- Diabetes mellitus

- Patients on cytotoxic drugs

\section{Study protocol:}

The data was collected in the Central Research Laboratory. Ethical clearance was obtained from the Institutional Ethical committee. Detailed experimental protocol was explained. A detailed history and medical examination was carried out. Smoking history regarding the duration and number of cigarettes smoked was obtained. $3 \mathrm{ml}$ of blood was drawn from median cubital vein and was subjected to COMET assay for detection of DNA damage.

\section{Comet assay}

The Single Cell Gel Electrophoresis assay (also known as comet assay) is an uncomplicated and sensitive technique for the detection of DNA damage at the level of the individual eukaryotic . . It involves the encapsulation of cells in a low-melting-point agarose suspension, lysis of the cells in neutral or alkaline $(\mathrm{pH}>13)$ conditions, and electrophoresis of the suspended lysed cells. This is followed by visual analysis with staining of DNA and calculating fluorescence to determine the extent of DNA damage. This can be performed by manual scoring or automatically by imaging software.

\section{Results :}

A total of 50 patients were considered for the statistical analysis. They were divided into 2 groups: group 1 consisted of smokers $(n=30)$ and group 2 consisted of nonsmokers $(n=20)$.

Table 1 shows the base line characteristics of the 2 groups. There was no statistically significant variation in the 2 groups. Table 2 compares the \% DNA in tail, tail moment and olive moment of the 2 groups. Using the MANNWHITNEY test, we found no statistically significant difference in the 2 groups. The difference in the DNA damage in the 2 groups was present, but this difference however was statistically insignificant ( $p>0.05)$.

\section{Discussion :}

Cigarette smoke is a major source of free radicals and tobacco smoke contains oxidants and pro-oxidant agents. It is also known to contain many mutagens/ carcinogens, with polycyclic aromatic hydrocarbons (PAHs), aromatic amines, $\mathrm{N}$-nitrosamines and aldehydes representing the major classes of harmful substances. Comet assay can sensitively detect DNA single strand break and alkali-labile site. It was used in this study to examine lymphocyte DNA damage of smokers.

The present study compared the DNA damage in peripheral blood lymphocytes in 30 smokers and 20 nonsmokers by using the COMET assay. We compared the \% DNA in tail, tail moment and olive moment of the 2 groups. 
As per our studies, we did not find any statistical difference in these values among the 2 groups $(p<0.05)$. Some studies done before by Manuel et al, Sram et al in 1998, Tates et al in 1996 have showed significant difference in the genotoxicity in the blood lymphocytes by using the COMET assay. ${ }^{[18-20]}$ Other studies have shown difference by using other techniques such as MN assay. ${ }^{[21]}$ Our results are not in accordance with these studies. Perhaps our sample size was too small. When the duration of smoking was correlated with the same 3 parameters, there was no statistical significance. However, there are other studies which do support our result.. Polasa et al. compared the DNA damage in 10 smokers and 10 non-smokers by using the comet assay and also found no significant outcome ( $p>$ $0.05)^{[22]}$

The comet assay has repeatedly been used to measure DNA damage related to tobacco smoking in various studies. However, conflicting results have been reported. It is possible that physiological, environmental and many other factors contribute to the overall variation of the comet assay. There have been no satisfactory descriptions of the effect of single factors or of the manner in which single factors interact with each other. Some possible factors that

Table 1: Subject characteristics (data expressed as mean \pm sd)

\begin{tabular}{|l|c|c|}
\hline CHARACTERISTICS & $\begin{array}{c}\text { GROUP I (SMOKERS) } \\
\mathrm{N}=30\end{array}$ & $\begin{array}{c}\text { GROUP II } \\
\text { (NON-SMOKERS) } \\
\mathrm{N}=20\end{array}$ \\
\hline AGE (YEARS) & $43.90 \pm 11.657$ & $41.05 \pm 9.747$ \\
\hline WEIGHT (kg) & $55.89 \pm 7.808$ & $56.85 \pm 3.631$ \\
\hline HEIGHT (m) & $1.656 \pm .0693$ & $1.653 \pm .0733$ \\
\hline $\begin{array}{l}\text { SYSTOLIC BLOOD } \\
\text { PRESSURE (mm of hg) }\end{array}$ & $124.60 \pm 10.138$ & $125.00 \pm 6.473$ \\
\hline $\begin{array}{l}\text { DIASTOLIC BLOOD } \\
\text { PRESSURE (mm of hg) }\end{array}$ & $82.60 \pm 82.60$ & $81.90 \pm 4.376$ \\
\hline
\end{tabular}

\section{References:}

1. Gurel E, Orta T, Gunebakan S, Utkusavao A, Kolusayin Ozar MO. Can micronucleus technique predict the risk of lung cancer in smokers? Tuberk Toraks 2005;53:225-30.

2. Wiesman $H$, Halliwell B. Damage to DNA by reactive oxygen species and nitrogen species: role of inflammatory disease and progression to cancer. Biochem J 1996;313:17 - 29.

3. Halliwell B. Oxidants and human disease: some new concepts. FASEB 1987;1:358-364

4. Nakayama T, Kaneko M, Kodama M, Nagata C. Cigarette smoke induces DNA single-strand breaks in human cells. Nature 1985;314:462-4. are said to cause variation in the level of DNA damage in healthy untreated individuals are: age, gender, air pollution, diet, exercise, sunlight, and smoking. These factors could lead to a change in DNA status in healthy individuals and the subjects, for which our study did not account for. Further studies with strict criteria for selection of subjects and controls are required to find the exact correlation between smoking and genotoxicity.

\section{Conclusion :}

Our study concludes that smoking genotoxicity as measured by comet assay in the peripheral blood lymphocytes does not vary significantly among smokers and non-smokers. Even though various studies have showed significant damage to DNA in smokers by using the comet assay, there have also been studies which were inconclusive. Hence, better modalities which are standardized are required to detect the genomic defects. More studies must be undertaken to validate the efficacy of COMET assay. Studies with a larger sample size must be undertaken to come to a better conclusion and understanding. Our study can be used as a pilot study to further explore the relation between smoking and DNA damage.

Table 2 : \% DNA in tail, tail moment and olive moment of various groups (data expressed as mean \pm sd)

\begin{tabular}{|l|c|c|}
\hline PARAMETERS & $\begin{array}{c}\text { GROUP I (SMOKERS) } \\
\mathrm{N}=30\end{array}$ & $\begin{array}{c}\text { GROUP II } \\
\text { (NON-SMOKERS) } \\
\mathrm{N}=20\end{array}$ \\
\hline \% DNA IN TAIL & $23.11 \pm 8.24$ & $27.702 \pm 5.67 *$ \\
\hline TAIL MOMENT & $7.48 \pm 2.34$ & $5.98 \pm 4.70^{*}$ \\
\hline OLIVE MOMENT & $9.42 \pm 1.27$ & $13.89 \pm 2.01 \#$ \\
\hline $\mathrm{Z}=-.246 \quad \mathrm{ZZ}=-.641$ \\
$\mathrm{p}=0.805 \quad \mathrm{p}=0.522$
\end{tabular}

5. Yang $\mathrm{Q}$, Hergenhahn $\mathrm{M}$, Weninger $\mathrm{A}$, Bartsch $\mathrm{H}$. Cigarette smoke induces direct DNA damage in the human B-lymphoid cell line. Carcinogenesis 1999;20:1769-75.

6. . Kato T, Nagasawa H, Warner C, Okayasu R, Bedford JS. Cytotoxicity of cigarette smoke condensate is not due to DNA double strand breaks: Comparative studies using radiosensitive mutant and wildtype $\mathrm{CHO}$ cells. Int J Radiat Biol 2007;83:583-91.

7. Albino AP, Huang $X$, Jorgensen ED, Gietl D, Traganos F, Darzynkiewicz Z. Induction of DNA double-strand breaks in A549 and normal human pulmonary epithelial cells by cigarette smoke is mediated by free 
radicals. Int J Oncol 2006;28:1491-1505.

8. Kassie F, Parzefall W, Knasmuller S. Single cell gel electrophoresis assay: a new technique for human biomonitoring studies. Mutat Res 2000;463:13-31.

9. Rojas E, Lopez MC, Valverde M. Single cell gel electrophoresis assay methodology and applications. J Chromatogr B Biomed Sci App 1999; 722:225-254.

10. Calini V, Urani C, Camatini M. Comet assay evaluation of DNA singleand double-strand breaks induction and repair in C3H10T1/2 cells. Cell Biol Toxicol 2002;18:369-379.

11. Chu G. Double strand break repair. J Biol Chem 1997;272:24097-100.

12. Tice RR, Agurell E, Anderson D, Burlinson B, Hartmann A, Kobayashi H et al., Single cell gel/comet assay: guidelines for in vitro and in vivo genetic toxicology testing. Environ. Mol. Mutagen 2000;35:206-21.

13. Hartmann A, Agurell E, Beevers C. et al. Recommendations for conducting the in vivo alkaline comet assay. Mutagenesis 2003;18:45-51.

14. Brendler-Schwaab S, Hartmann A, Pfuhler S, Speit G. The in vivo comet assay: use and status in genotoxicity testing. Mutagenesis 2005;20:245-54.

15. Moller P, Knudsen LE, Loft S, Wallin $\mathrm{H}$. The comet assay as a rapid test in biomonitoring occupational exposure to DNA-damaging agents and effect of confounding factors. Cancer Epidemiol 2000; Biomarkers Prev;9:1005-15.

16. Faust F, Kassie F, Knasmuller S, Boedecker RH, Mann M, MerschSundermann V. The use of the alkaline comet assay with lymphocytes in human biomonitoring studies. Mutat Res 2004;566:209-29.

17. Hellman B, Vaghef $H$, Bostro"m B. The concepts of tail moment and tail inertia in the single cell gel electrophoresis assay. Mutat Res 1995; 336:123-31.

18. Manuel F. Ellahueñe, Luz Patricia Pérez-Alzola, Mauricio Farfán-Urzua, et al. Cancer Epidemiol Biomarkers Prev 2004;13:1223-9.

19. Sram RJ, Binkova B. Molecular epidemiology studies on occupational and environmental exposure to mutagens and carcinogens, 1997-1999. Environ Health Perspect 2000;108:57-70.

20. Tates AD, van Dam FJ, de Zwart FA, et al. Biological effect monitoring in industrial workers from the Czech Republic exposed to low levels of butadiene. Toxicology 1996;113, 91-99.

21. Ayse G Zamani, H Gul Durakbasi-Dursun, Sennur Demirel, Aynur Acar, Evaluation of smoking genotoxicity in Turkish young adults, Indian J Hum Genet 2011;17:7-12

22. Polasa K, Naidu AN, Ravindranath I, Krishnaswamy K. Inhibition of $\mathrm{B}[\mathrm{a}] \mathrm{P}$ induced strand breaks in presence of curcumin. Mutat Res 2004;557:203-13. 